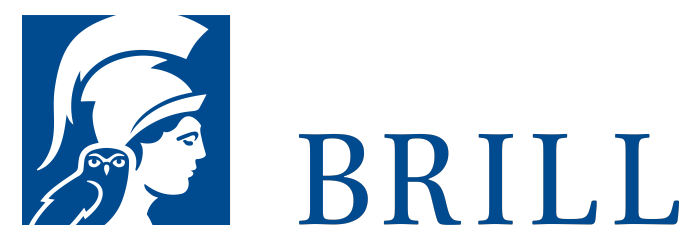

\title{
Jesus als Held
}

Odysseus und Herakles als Vorbilder christlicher Heldentypologie

Author: Henrike Maria Zilling

Mythologische VorBilder des gekreuzigten Gottessohnes. Der Aufstieg des Gekreuzigten zum Heiland ist nicht ohne die Vorbilder der griechischen Helden mÃ $\llbracket$ glich gewesen. Ihr Mythos war fest im kulturellen GedÃ achtnis der Menschen verankert, so dass sich in einem vielschichtigen Umdeutungsprozess ein christliches Heldenkonzept entwickelte. Der Tod des Gekreuzigten wird so zum Triumph des Gottessohnes. Es zeigt sich, dass auch der an den Mastbaum seines Schiffes fixierte Odysseus in der Predigt der KirchenvÃater eine christliche Transformation erlebt. Genauso wie Herakles am Scheideweg allen Abgrenzungsversuchen zum Trotz eine christliche Interpretation und Aneignung erfã ahrt. Die Passionsgeschichte vor diesem Hintergrund lesen, erÃ Iffnet neue kulturgeschichtliche Perspektiven fã $1 / 4$ r ein Verstãandnis der Christusfigur.

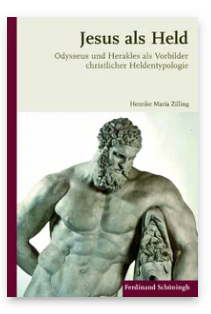

Pages: 288

Seiten, $21 \mathrm{~s} / \mathrm{w}$

Abb.

Language:

German

Subjects:

Ancient History,

Classical Studies

Publisher: Brill |

SchÃ ๆningh

E-Book (PDF)

Released online:

O2 Jan 2012

ISBN: 978-3-

657-77236-о

List price

USD Â $\$ 63.00$

Hardback

Publication date:

o5 Oct 2011

ISBN: 978-3-

506-77236-7

List price

USSD Â $\$ 63.00$ 
Henrike Maria Zilling, PD Dr.phil., Studium der Geschichte und Biologie an der FU und der TU Berlin; 2009/10 Habilitation und Ernennung zur PD am Institut $\mathrm{f} \tilde{\mathrm{A}} 1 / 4 \mathrm{r}$ Kunstgeschichte und historische Urbanistik der TU Berlin. Ihr Buch Â»Tertullian.

Untertan Gottes und des KaisersÂ« ist 2004 im Verlag Ferdinand SchÃ ๆningh erschienen.

For more information see brill.com

Order information: Order online at brill.com +44330 3330049 | customerservices@brill.com Submission information: brill.com/authors

Titles published by Brill | Fink, Brill | mentis or Brill | Schöningh: +49(o)715413279216| brill@brocom.de 